\title{
Cell Proliferative and Cell Cycle Effects of Atrazine Using Human Breast Cell Lines
}

\author{
Egbe Egiebor $^{1 *}$, Nadia Abou Zeid ${ }^{2}$ and Ali Ishaque ${ }^{1}$ \\ ${ }^{1}$ Department of Public health, University of Illinois Springfield, USA \\ ${ }^{2}$ Toxicology Program, University of Maryland Eastern Shore, USA
}

*Corresponding author: Egbe Egiebor, Department of Public Health, University of Illinois Springfield, One University Plaza, USA.

To Cite This Article: Egbe Egiebor. Cell Proliferative and Cell Cycle Effects of Atrazine Using Human Breast Cell Lines. Am J Biomed Sci \& Res. 2019 - 4(6). AJBSR.MS.ID.000846. DOI: 10.34297/AJBSR.2019.04.000846

Received: 阱August 22, 2019; Published: 眥August 26, 2019

\begin{abstract}
Breast cancer is one of the leading causes of cancer related deaths in women. Several risk factors can increase breast cancer occurrences and strong evidence has shown that exposure to endocrine disrupting chemicals including atrazine can lead to breast cancer etiology. This study examined the effect of low level/environmentally relevant concentrations of atrazine on two breast cell lines (MCF-7, an estrogen responsive breast cancer cell line and MCF-10A, a non-cancerous human breast epithelial cell line) by studying cytotoxicity, proliferation and cell cycle events. To study cytotoxicity, cells were exposed to atrazine within a concentration range of $0.315 \mu \mathrm{g} / \mathrm{L}$ to 100,000 $\mu \mathrm{g} / \mathrm{L}$ for $96 \mathrm{~h}$ and cell proliferation as well as the LC50 were calculated at 24, 48,72 and $96 \mathrm{~h}$ using the RT-CES. Cell cycle was studied by exposing the cell to $3 \mu \mathrm{g} / \mathrm{L}$ atrazine, and nuclei was isolated and analyzed using a BD FACSCalibur. The percentage nuclei in the cell cycle was calculated using Modfit LT 3.0. Results showed that there was an overall decreased in LC50 over time in both cell lines. Exposure of MCF-7 and MCF-10A to $3 \mu \mathrm{g} / \mathrm{L}$ of atrazine for $96 \mathrm{~h}$, stimulated an increase in cell proliferation compared to control. Lower concentrations of atrazine showed even stronger impact on cell proliferation. However, ATR induced more cell proliferation in MCF-7 than in MCF-10A. Significant increases were recorded in the percent nuclei in G1 and G2 phases of MCF-7 cells exposed to ATR. Increase in the percent nuclei was only recorded in the G1 phase in MCF- 10A cells exposed to ATR. This adds to the body of evidence that ATR may indeed play a significant role in the onset and progression of cancer.
\end{abstract}

Keywords: MCF-7; MCF-10A; Atrazine; Breast Cancer

\section{Introduction}

Breast cancer is the most frequent cancer among women, and it impacts 2.1 million women each year [1]. It is estimated that 627,000 women died from breast cancer (approximately 15\% of all cancer deaths in women) in 2018 [1]. Although breast cancer occurrence is rare among men, it is estimated that 2,670 will be diagnosed with breast cancer in 2019 [2]. The etiology of breast cancer has been linked to several factors including family history/ hereditary of BRCA1 and BRCA2 genes, hormone replacement therapy, obesity and alcohol [3-5]. In addition, studies have shown that ovarian hormones, including estrogen and progesterone, may increase breast cancer risk by affecting rates of cell proliferation in the breast or by supporting enhanced cellular growth induced by estrogen dependent tumors [6]. Furthermore, exposure to environmental pollutant including endocrine disruptors chemicals (EDC) have been implicated as potential risk factor in developing breast tumors [7].

Environmental pollutants including herbicides have been shown to affect cell proliferation and therefore lead to the onset of diseases $[8,9]$. Low level herbicide such as atrazine (ATR) exposure can result in many adverse effects causing DNA damage, chromosomal aberration, cell cycle perturbation, as well as reproductive and developmental alteration [8,10,11]. Atrazine (2-chloro-4ethylamino-6-isopropyl-amino-s-triazine) is a ubiquitous broadspectrum herbicide frequently used in corn and soy fields. ATR contaminates water sources via agricultural runoffs (Solomon et al., 1996). More than thirty-four million kg of ATR are applied each year in the United States. Even though the U.S. Environmental Protection Agency (EPA) enforces a maximum contaminant level (MCL) of ATR at $3.0 \mu \mathrm{g} / \mathrm{L}$ ( $3 \mathrm{ppb}$ ), studies have revealed that ATR concentrations in some areas have exceeded the MCL in public drinking water sources, and the concentration in groundwater could range from below3 $\mu \mathrm{g} / \mathrm{L}$ to as high as $700 \mu \mathrm{g} / \mathrm{L}$ [12-14]. In 2003 the European Union banned the use of ATR because of its prevalence in drinking water contamination; however, the EPA permitted its continued use in the US that same year [15].

ATR is believed to be a potent endocrine disruptor $[16,17]$ that can cause demasculinization and feminization [18] and can also induce adverse effects on different biological systems. For 
example, ATR can affect the reproductive system $[19,20]$ the central nervous system [21], and the immune system [22] Since ATR exposure has been associated with cancer development, increased cell proliferation is an expected outcome after exposure as demonstrated in human intestinal epithelial cells [23]. In fact, a study by [24] showed that exposure to ATR induced cell proliferation in human BG-1 and 2008 ovarian cancer cells in a concentration dependent manner. Epidemiological studies have also related increased risk of ovarian cancer in female farm workers in Italy [25] and increased risk of breast cancer in the population of Kentucky to ATR exposures [26]. ATR does not bind or activate the classical estrogen receptor (ER) [24], but scientists have speculated other estrogen related pathways. For example, ATR may induce aromatase (CYP19) activity, converting testosterone and related hormones to estrogens, thus it increases estrogen levels [27]. Other studies have contradicted the endocrine disrupting effects of ATR. Studies funded by Syngenta concluded that there was no causal relationship between exposures to ATR and development of breast cancer [28]. Contradictory results were also found in another study in which higher levels of mixed pesticides, including ATR, were associated with increased breast cancer in one rural county in the UK, but not in a nearby county [29]. ATR is also known to induce alterations in normal cell cycle progression. Studies by Freeman and Rayburn [30] reported that there was a decrease in cells in the G2 phase when Chinese Hamster Ovary (CHO) cells were exposed to ATR [31]. also saw similar results when Hep2G cells were exposed to ATR.

Even though a few researchers have studied the Proliferative effects of ATR using different cell lines, studies of the effects of ATR on cell cycle in human breast cell lines are scarce. Since endocrine disruptors like ATR act like natural hormones which are available in low doses, this study explored the effect of low level/ environmentally relevant concentrations of ATR on two human breast cell lines (MCF-7, an estrogen responsive breast cancer cell line and MCF-10A, a non-cancerous human breast epithelial cell line) by studying cytotoxicity and cell cycle events. The study will help scientists understand whether ATR will increase the risk of women who have already been diagnosed with breast cancer and those who have not.

\section{Material and Methods}

\section{Reagents}

MCF-7 and MCF-10A cell lines were purchased from American Type Culture Collection (ATTC, Manassas, VA, USA). Minimum Essential Medium (MEM) alpha 1x, Dulbecco's Phosphate Buffered Saline (PBS), Dulbecco's Modified Eagle's Medium (DMEM), MEM without phenol, and penicillin streptomycin were purchased from GIBCO Invitrogen (Grand Island, NY, USA). Trypsin-EDTA and fetal bovine serum (FBS) were purchased from ATTC. All other supplements were purchased from Cambrex Bio Science. Walkersville, Inc., USA.

\section{Cell Culture}

Both MCF-7 and MCF-10A cell lines were incubated at $37^{\circ} \mathrm{C}$ in 5\% CO2 and humidified atmosphere. When MCF-7 cells reached 75-80\% confluency, they were washed with phosphate buffer saline (PBS), trypsinized with $3 \mathrm{ml}$ of $0.25 \% \mathrm{w} / \mathrm{v}$ trypsin, $0.53 \mathrm{mM}$ EDTA and incubated at 37C for 5 minutes. For MCF-10A cells, 3.0 $\mathrm{ml}$ of a $0.05 \%$ trypsin, $0.53 \mathrm{mM}$ EDTA solution was added and cells were incubated at $37 \mathrm{C}$ for 15 minutes. At the end of the incubation period, $3 \mathrm{ml}$ of a solution of $0.1 \%$ soybean trypsin inhibitor was added to the MCF10 A to neutralize the trypsin. Both cells types were centrifuged at $3000 \mathrm{rpm}$ for 2 minutes at $4^{\circ} \mathrm{C}$. Both cell lines were diluted with MEM, washed with saline and centrifuged at $5000 \mathrm{rpm}$ for 5 minutes at $4^{\circ} \mathrm{C}$. Cells were counted with Beckman counter and used for exposure assays.

\section{Description of Exposure Studies}

Real-Time Cell Electronic Sensing (RT-CES): Cell viability and cytotoxicity effects of ATR on MCF-7 and MCF-10A cells were determined by RT-CES assay (ACEA Biosciences Inc., San Diego, CA, USA). Cell viability was monitored every $10 \mathrm{~min}$ for $96 \mathrm{~h}$ by the detection of cell impedance as a measure of cell number morphology and adherence. Continuous recording of impedance in cells was reflected by cell index (CI) value which corresponds to cell growth [31].

Cytotoxicity of ATR on MCF-7 and MCF-10A cell lines Using RT-CES: To determine the cytotoxicity of the ATR, MCF-7 and MCF-10A cells were seeded in a 16x E-plate device and grown in the incubator. After $24 \mathrm{~h}$, the cells were treated with ATR. Serial dilution as described by [9] were followed. To create a negative control, the last row of cell culture plate contained the media and cells but was not exposed to ATR. Cells were exposed to ATR within a concentration range of $0.315 \mu \mathrm{g} / \mathrm{L}$ to $100,000 \mu \mathrm{g} / \mathrm{L}$ for $96 \mathrm{~h}$ and the lethal concentration at which $50 \%$ of the cells died (LC50) was calculated at 24, 48,72 and $96 \mathrm{~h}$. In addition, CI was derived to represent cell status based on measured electrical impedance. A rise in CI (rise in electrical impedance) indicated cell proliferation and a drop in CI (drop in electrical impedance) indicated cell death. The experiment was conducted three separate times. ANOVA followed by mean separation using LSD at $\alpha=0.05$ was also calculated [32].

\section{Cell Cycle Analysis}

Both cell lines were exposed to $3 \mu \mathrm{g} / \mathrm{L}$ environmentally realistic concentrations of ATR. Eighty pico-gram $/ \mathrm{ml}$ of estrogen was used as a positive control for measuring estrogenic activity of the cell lines. After $96 \mathrm{~h}$ exposure period, nuclei were isolated from exposed and control cells then stained with propidium iodide (PI) using a hypotonic lysis solution [33]. Briefly, cells were washed with sterile $1 \%$ PBS, followed by the addition of $1.5 \mathrm{ml}$ of the PI solution $(0.05 \mathrm{mg} / \mathrm{ml}, 0.1$ Triton $X 100,0.1 \%$ sodium citrate, 7 unites /ml RNAse). Plates were refrigerated and tilted every 3-5 minutes to release the nuclei from the lysed cells. The samples were 
filtered through a 53-um mesh filter and kept on ice until analysis. The refrigeration time differed for each cell line. MCF-7 cells were refrigerated for one hour and MCF-10A cells were refrigerated for 6 hours as nuclei from MCF10Atakes longer time to be collected than does MCF-7 cells. The isolated nuclei were then analyzed using a BD FACSCalibur equipped with 4-Color filters; $530 \mathrm{~nm}$ (FITC), $585 \mathrm{~nm}$ (PE/PI), 670nm (PerCP) and $661 \mathrm{~nm}$ (APC), (San Diego, LA, USA). The excitation wavelength (488 $\mathrm{nm}$ ) was provided by a $5 \mathrm{~W}$ argon ion laser. Approximately 20,000 nuclei per sample were analyzed. The percentage of nuclei of the cell cycle was calculated using Modfit LT 3.0 (Verity Software House Inc., Topsham, ME, USA). ANOVA followed by mean separation using LSD at $\alpha=0.05$ was performed on the percentage of nuclei in the G1, S (synthesis), and G2 phases of the cell cycle.

\section{Results}

\section{Cytotoxicity of ATR on MCF-7 and MCF-10A cell lines}

Median lethal concentration (LC50) is the most widely used criterion for acute toxicity testing. LC50 is described as the concentration of a substance that kills $50 \%$ of the test organisms after a specific length of exposure, usually $96 \mathrm{~h}$. The LC50 for MCF-7 cells exposed to ATR were 14,960, 22,100, 14,700 and 14,100 $\mu \mathrm{g} / \mathrm{L}$ for $24 \mathrm{~h}, 48 \mathrm{~h}, 72 \mathrm{~h}$ and $96 \mathrm{~h}$ respectively. The LC50 for MCF- 10A were $36,660,9,870,9,940$ and 1,200 $\mu \mathrm{g} / \mathrm{L}$ for $24 \mathrm{~h}, 48 \mathrm{~h}, 72 \mathrm{~h}$ and 96 $\mathrm{h}$ respectively (Table 1 ).

\begin{tabular}{|c|c|c|}
\hline \multicolumn{3}{|c|}{ Table 1: LC50 (ug/L) of ATR on MCF-7 and MCF-10A cell lines. } \\
\hline \multicolumn{3}{|c|}{ Mean \pm Std. Dev } \\
\hline Time & MCF-7 & MCF10-A \\
\hline 24 & $14960 \pm 0.424 \mathrm{~B}$ & $36660 \pm 0.23 \mathrm{C}$ \\
\hline 48 & $22100 \pm 0.694 \mathrm{~A}$ & $9870 \pm 0.12 \mathrm{~B}$ \\
\hline 72 & $14700 \pm 0.249 \mathrm{~B}$ & $9940 \pm 0.09 \mathrm{~B}$ \\
\hline 96 & $14100 \pm 0.282 \mathrm{~B}$ & $1200 \pm 0.16 \mathrm{~A}$ \\
\hline
\end{tabular}

*Means within a column lacking a common letter are significantly difference $(p \leq 0.001)$

\section{Cell Proliferation After ATR Exposure}

Cell lines were exposed to ATR concentrations ranging from $0.315 \mu \mathrm{g} / \mathrm{L}$ to $100,000 \mu \mathrm{g} / \mathrm{L}$. Results showed that exposure of MCF7 breast cancer cells to $3 \mu \mathrm{g} / \mathrm{L}$ ATR (EPA MCL) for $96 \mathrm{~h}$ stimulated an increase of $20 \%$ cell proliferation compared to control (Figure 1). Lower concentrations than the EPA MCL for ATR showed even stronger impact on cell proliferation, for example, $1.5 \mu \mathrm{g} / \mathrm{L}$ increased cell proliferation by $31 \%$ as compared to control. ATR concentration of $0.75 \mu \mathrm{g} / \mathrm{L}$ also caused growth to increase by $11 \%$. ATR concentrations higher than 25,000 $\mu \mathrm{g} / \mathrm{L}$ induced cell death in MCF-7.

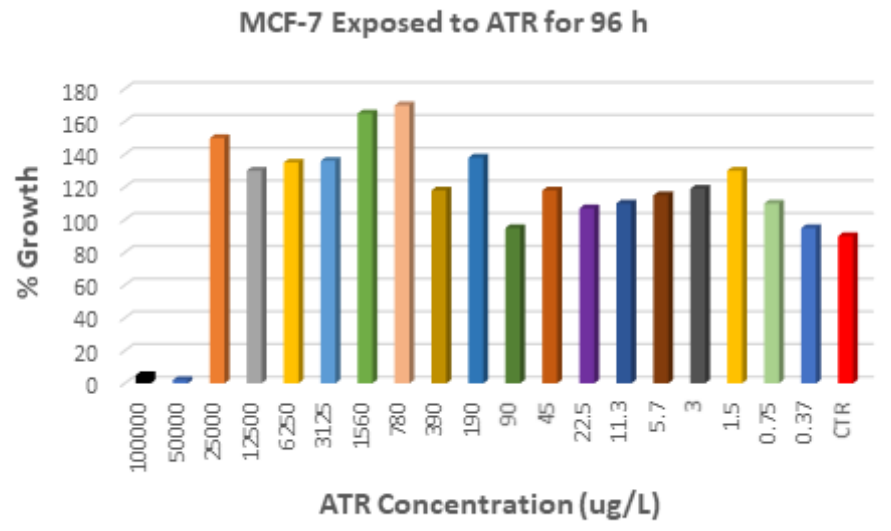

Figure 1: Breast Cancer Cell Line (MCF-7) Exposed to ATR for $96 \mathrm{~h}$.

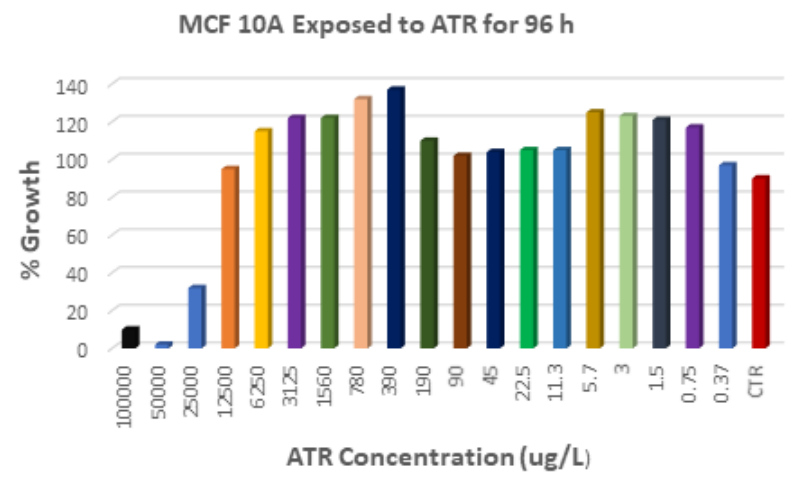

Figure 2: Normal Breast Cell Line (MCF-10A) Exposed to ATR for $96 \mathrm{~h}$. 
After $96 \mathrm{~h}$ of exposure, ATR concentrations of $3 \mu \mathrm{g} / \mathrm{L}$ stimulated $25 \%$ increase in cell proliferation in MCF-10A breast cells compared to control (Figure 2). Lower concentrations as $1.5 \mu \mathrm{g} / \mathrm{L}$ and $0.75 \mu \mathrm{g} / \mathrm{L}$ showed almost same stimulatory effect. Higher concentrations of ATR: $390 \mu \mathrm{g} / \mathrm{L}$ and $780 \mu \mathrm{g} / \mathrm{L}$ induced the highest increase in cell growth; $37 \%$ and $32 \%$ more than control respectively. Concentrations higher than $12500 \mu \mathrm{g} / \mathrm{L}$ induced cell death.

\section{Impact of ATR on cell cycle}

To determine the effect of ATR on cell cycle, both Cell lines were exposed to the EPA MCL concentration of ATR for $96 \mathrm{~h}$. The result indicated that there was a significant increase in the $\%$ nuclei in the G1 and G2 phases of MCF-7 cell lines; however, there was no increase in the S phase. MCF-10 A cells showed a significant increase in the \% nuclei in the G1 phase but there was not increase in \% nuclei in the G2 or S Phase (Table 2, Table 3 \& Table 4).

Table 2: G1 Phase Analysis of both cell lines after $96 \mathrm{~h}$ of exposure.

\begin{tabular}{|c|c|c|}
\hline \multirow{2}{*}{ TRT } & \multicolumn{2}{|c|}{$* \%$ G1 phase \pm Std. Dev } \\
\cline { 2 - 3 } & MCF-7 & MCF10-A \\
\hline CTR & $94.57 \pm 0.92 \mathrm{C}$ & $75.88 \pm 1.75 \mathrm{EF}$ \\
\hline EST & $94.59 \pm 1.11 \mathrm{C}$ & $75.89 \pm 0.70 \mathrm{~F}$ \\
\hline ATR & $98.21 \pm 0.41 \mathrm{~A}$ & $78.7 \pm 0.62 \mathrm{D}$ \\
\hline
\end{tabular}

*Means within a column lacking a common letter are significantly difference $(p \leq 0.001)$

Table 3: S Phase Analysis of both cell lines after $96 \mathrm{~h}$ of exposure.

\begin{tabular}{|c|c|c|}
\hline \multirow{2}{*}{ TRT } & \multicolumn{2}{|c|}{$* \%$ S phase \pm Std. Dev } \\
\cline { 2 - 3 } & MCF-7 & MCF10-A \\
\hline CTR & $4.58 \pm 0.78 \mathrm{C}$ & $22.26 \pm 0.11 \mathrm{~A}$ \\
\hline EST & $5.02 \pm 1.06 \mathrm{BC}$ & $21.79 \pm 0.31 \mathrm{AB}$ \\
\hline ATR & $0.09 \pm 0.05 \mathrm{E}$ & $20.97 \pm 0.47 \mathrm{~B}$ \\
\hline
\end{tabular}

*Means within a column lacking a common letter are significantly difference $(p \leq 0.001)$

Table 4: G2 Phase Analysis of both cell lines after $96 \mathrm{~h}$ of exposure.

\begin{tabular}{|c|c|c|}
\hline \multirow{2}{*}{ TRT } & \multicolumn{2}{|c|}{$*$ \% G2 phase \pm Std. Dev } \\
\cline { 2 - 3 } & MCF-7 & MCF10-A \\
\hline CTR & $0.85 \pm 0.14 \mathrm{~B}$ & $1.86 \pm 1.86 \mathrm{CD}$ \\
\hline EST & $0.39 \pm 0.25 \mathrm{DE}$ & $2.32 \pm 0.63 \mathrm{BC}$ \\
\hline ATR & $1.70 \pm 0.41 \mathrm{~A}$ & $0.33 \pm 0.33 \mathrm{DE}$ \\
\hline
\end{tabular}

*Means within a column lacking a common letter are significantly difference $(p \leq 0.001)$

\section{Discussion}

Cytotoxic effects of environmentally relevant concentrations of ATR on breast cancer cells (MCF-7) and normal breast cells (MCF10A) were assessed using RT-CES. The E-plates in the instrument are equipped with microelectrodes which causes changes in electrical impedance. Thus, higher cell index indicate that more cells are bound to the microelectrodes. ATR action was recorded online after cell attachment and continuous information about growth, morphological changes and cell death were collected in real time.

LC50 is the concentration of a substance that kills $50 \%$ of its test subjects when administered in a single dose. Acute toxicity data are very important because they are used to set guidelines for regulatory measures (PHAGM, 2005). The current study showed that the effect of ATR was time dependent; in general, toxicity increased as exposure time increased. Although, we found a significant decrease in ATR toxicity on MCF 7 after $48 \mathrm{~h}$. However, a significant increase of ATR on MCF 7 cells was recorded after $72 \mathrm{~h}$. This is in accordance with the findings that showed that the toxicity of ATR in C. Puctatus is both time and concentration dependent [34] Although, their study found the LC50 of a $96 \mathrm{~h}$ ATR exposure for C. puctatus to be $42,381 \mu \mathrm{g} / \mathrm{L}$ which was quite high compared to our findings. The LC50 found in this current study (14, 100 and $1,200 \mu \mathrm{g} / \mathrm{L}$ for MCF-7 and MCF-10A respectively) is closer to results obtained from previous studies [35-37] that reported the LC50 for ATR after $96 \mathrm{~h}$ exposure to be 16,000, 18800 and $9370 \mu \mathrm{g} / \mathrm{L}$ for Lepomis macrochirus, Cyprinus carpio and Oreochromis niloticus, respectively. Different cytotoxicity studies have shown that ATR exposure caused changes in erythrocytes membranes, DNA damage, mitochondrial dysfunction, cell autophagy and apoptosis $[38,39]$. Ultimately, the cellular changes may lead to severe adverse health effects including cancer.

It has since been purported that ATR, a potent EDC, could induce proliferative effect on breast cancer cells through aromatase activation [27] as well as GPR30 binding [40]. The current study indicates that both cell lines exposed to low environmentally relevant concentrations of 3 ATR for $96 \mathrm{~h}$ stimulated cell proliferation. However, exposure of cell lines to the concentration of ATR higher that 25,000 $\mu \mathrm{g} / \mathrm{L}$ (MCF-7) and 12,500 $\mu \mathrm{g} / \mathrm{L}$ (MCF$10 \mathrm{~A})$ caused cell death. It is important to note however, that the proliferative effect of ATR in the current study was greater in MCF7 than in MCF-10A. The increased proliferation may be attributed to the fact that MCF-7 is estrogen responsive and it yielded more response to ATR's endocrine disrupting effects. Our findings are in line with the study that showed that ATR enhanced transcription of the aromatase gene as well as estrogen production in estrogen responsive breast cell [41,42]. Similarly, studies by [43] found that there was an increase in cell proliferation when MCF-7 cell were exposed to environmentally relevant concentrations. However, they did not record any increase in cell proliferation in MCF 10A. Even though the EPA has a set MCL of $3 \mathrm{ppb}$, it is very worrisome to know that lower levels can induce cell growth and therefore cancer cell proliferation. ATR has been classified as non-carcinogenic by the EPA, however, strong evidence suggests otherwise. Scientist continue to record more environmental and human adverse effects due to exposure [43] including increased risk of ovarian cancer in female farm workers in Italy [25] and increased risk of breast cancer in the population of Kentucky to ATR exposures [26]. 
To our knowledge, our team is the first to investigate the cell cycle effects of ATR on MCF-7 and MCF 10A cells. The cell cycle investigation in the present study buttresses the body of evidence that implicates ATR in the etiology of breast cancer as cell proliferation was confirmed by a significant increase in the $\%$ nuclei in the G1, and G2 phases in MCF-7. However, significant increase in \% nuclei was only recorded in G1 phase for MCF-10A. Increase of nuclei in cell cycle confirms cell duplication and proliferation. This finding is in agreement with a study conducted in HepG2 cell line, where 100, 300, and 500 ppb ATR exposure for $48 \mathrm{~h}$ caused nuclei to accumulate in S phase compared to control [31]. Similarly, studies using CHO cells exposed to 43ppm ATR, showed a significant accumulation of nuclei in $\mathrm{S}$ phase [30]. Although an increase in the $\%$ nuclei in the G phase was recorded in the current study, unlike previous studies, we did not record any increase in the \% nuclei in cells in the $\mathrm{S}$ phase. This variation may be attributed to the difference in the type of cell lines used in the study. Interestingly, estrogen did not elicit an increase the \% nuclei in any of the cell cycle phases in both cell lines. This suggests that estrogen may not exerts its endocrine disrupting effects through cell cycle activities. It is important to also note that even though ATR and estrogen elicit endocrine disrupting effects, ATR does not bind to or activate the classical estrogen receptor, but it up-regulates the aromatase activity in estrogen-sensitive tumor cells [24].

The current study examined the effects of ATR exposure on human breast cell. Specifically, ATR toxicity. Cell proliferation activity and cell cycle events were studied by exposing cells to different concentrations of ATR including very low concentrations that can be present in drinking water. In addition, two human breast cell lines were studied rather than non-human cell lines that are frequently published. The results obtained from studying human breast cell lines may prove more relevant in understanding the etiology of breast cancer in humans. It is imperative that more studies that elucidates the possible mechanistic pathways by which ATR induces cancer in human cells- specifically breast cells, be conducted.

\section{References}

1. (2019) World Health Organization.

2. (2019) Key Statistics for Breast Cancer in Men. American Cancer Society.

3. Rudolph A, Chang Claude J, Schmidt MK (2016) Gene-environment interaction and risk of breast cancer. Br J Cancer 114(2): 125-133.

4. Zhang XL, Wang HS, Liu N, Ge LC (2015) Bisphenol a stimulates the epithelial mesenchymal transition of estrogen negative breast cancer cells via FOXA1 signals. Arch Biochem Biophys 585: 10-16.

5. Colditz GA, Bohlke K (2014) Priorities for the primary prevention of breast cancer. CA Cancer J Clin 64(3): 186-194.

6. Mustafa A, Bland I (1998) Physiologic effects of steroid hormones and postmenopausal hormone replacement on the female breast and breast cancer risk. Ann Surg 228(5): 638-651.

7. McLachlan A 2001 Environmental signaling: what embryos and evolution teach us about endocrine disrupting chemicals. Endocr Rev Jun 22(3): 319-341.
8. Zeid, NA, Egiebor, E, Mack, K, Squibb, K, Aighewi, et al. (2014) Genotoxic Effect of Atrazine, Arsenic, Cadmium and Nitrate, Individually and in Mixtures at Maximum Contaminant Levels on mammalian Breast Cell Lines. Journal of African Association of Physiological Sciences 2(2): 130141.

9. Egiebor, E, Tulu A, Abou Zeid N, Aighewi IT, Ishaque A (2013) The kinetic signature of toxicity of four heavy metals and their mixtures on MCF7 breast cancer cell line. International journal of environmental research and public health 10(10): 5209-5220.

10. Biradar DP, Rayburn AL (1995) Chromosomal damage induced by herbicide contamination at concentrations observed in publicwater supplies. J Environ Qual 24(6): 1222-1225.

11. Biradar DP, Rayburn AL (1995) Flow cytogenetic analysis ofwhole cell clastogenicity of herbicides found in groundwater. Arch Environ Contam Toxicol 28(1): 13-17.

12. Zhu L, Dong X, Xie H, Wang J, Wang, et al. (2011) DNA damage and effects on glutathione-S-transferase activity induced by atrazine exposure in zebrafish (Danio rerio). Environ Toxicol 26(5): 480-488.

13. Shipitalo MJ, Owens LB (2003) Atrazine, deethylatrazine, and deisopropylatrazine in surface runoff from conservation tilled watersheds. Environmental science \& technology 37(5): 944-950.

14. Gfrerer M, Martens D, Gawik B, Wenzi T, Zhang A, et al. (2002) Triazines in the aquatic systems of the eastern Chinese Rivers Liao-He and Yangtse. Chemosphere 47(4): 455-466.

15. McBirney M, King SE, Pappalardo M, Houser E, Unkefer M, et al. (2017) Atrazine induced epigenetic transgenerational inheritance of disease, lean phenotype and sperm epimutation pathology biomarkers. PloS one 12(9): e0184306.

16. Yuan B, Liang S, Jin YX, Zhang MJ, Zhang JB, et al (2017) Toxic effects of atrazine on porcine oocytes and possible mechanisms of action. PloS one 12(6): e0179861.

17. Vandenberg LN, Colborn T, Hayes TB, Heindel JJ, Jacobs DR, et al. (2012) Hormones and endocrine-disrupting chemicals: Low-dose effects and nonmonotonic dose responses. Endocr Rev 33(3): 378-455.

18. Hayes TB, Anderson LL, Beasley VR, de Solla SR, Iguchi T, et al. (2011) Demasculinization and feminization of male gonads by atrazine: consistent effects across vertebrate classes. J Steroid Biochem Mol Biol 127(12): 64-73.

19. Betancourt M, Resendiz A, Fierro EC (2006) Effect of two insecticides and two herbicides on the porcine sperm motility patterns using computer-assisted semen analysis (CASA) in vitro. Reprod Toxicol 22(3): 508-512.

20. Spano L, Tyler CR, van Aerle R, Devos P, Mandiki SN, et al. (2004) Effects of atrazine on sex steroid dynamics, plasma vitellogenin concentration and gonad development in adult goldfish (Carassius auratus). Aquat Toxicol 66(4): 369-379.

21. Coban A, Filipov NM (2007) Dopaminergic toxicity associated with oral exposure to the herbicide atrazine in juvenile male C57BL/6 mice. J Neurochem 100: 1177-1187.

22. Rowe AM, Brundage KM, Barnett JB (2008) Developmental immunotoxicity of atrazine in rodents. Basic Clin Pharmacol Toxicol 102(2): 139145 .

23. Greenman SB, Rutten MJ, Fowler WM, Scheffler L, Shortridge LA, et al. (1997) Herbicide/pesticide effects on intestinal epithelial growth. Environ $\operatorname{Res} 75(1): 85-93$

24. Albanito L, Lappano R, Madeo A, Chimento A, Prossnitz ER, et al (2015) Effects of atrazine on estrogen receptor $\alpha$ - And G protein-coupled receptor 30-mediated signaling and proliferation in cancer cells and cancer-associated fibroblasts. Environ Health Perspect 123(5): 493-499.

25. Donna A, Cosignani P, Robutti F (1989) Triazine herbicides and ovarian epithelial neoplasms. Scand J Work Environ Health 15(1): 47-53. 
26. Kettles A, Browning R, Prince S, Horstman W (1997) Triazine herbicide exposure and breast cancer incidence: an ecologic study of kentucky counties. Environ Health Perspect 105(11): 1222-1227.

27. Sanderson JT, Letcher RJ, Heneweer M, Giesy JP, van den Berg M (2001) Effects of chloro-s-triazine herbicides and metabolites on aromatase activity in various human cell lines and on vitellogenin production in male carp hepatocytes. Environ Health Perspect 109(10): 1027-1031.

28. Boffetta P, Adam HO, Berry C, Mandel JS (2013) Atrazine and cancer: A review of the epidemiologic evidence. Eur J Cancer Prev 22(2): 169-180.

29. Muir K, Rattanamongkolgul S, Smallman Raynor M, Thomas M, Downer $S$, et al (2004) Breast cancer incidence and its possible spatial association with pesticide application in two counties of England. Public Health 118(7): 513-520.

30. Freeman JL, Rayburn AL (2006) Aquatic herbicides and herbicide contaminants: In vitro cytotoxicity and cell-cycle analysis. Environ Toxicol 21(3): 256-263.

31. Powell E, Faldladdin N, Rand A, Pelzer D, Erin M, et al. (2011) Atrazine exposure leads to altered growth of HepG2 cells. Toxicol in Vitro 25(3): 644-651.

32. Xing JZ, Zheu L, Jackson JA, Gabos S, Sun XJ, et al. (2005) Dynamic monitoring of cytotoxicity on microelectronic sensors. Chem Res Toxicol 18(2): 154-161.

33. Ghosh P, Banerjee M, De Chaudhuri S, Das JK, Sarma N, et al. (2007) Increased chromosome aberration frequencies in the Bowen's patientscompared to non-cancerous skin lesions individuals exposed to arsenic. Mutat Res 632(1-2): 104-110.

34. Nwani CD, Lakra WS, Nagpure NS, Kumar R, Kushwaha B, et al. (2010) Toxicity of the herbicide atrazine: effects on lipid peroxidation and activities of antioxidant enzymes in the freshwater fish Channa punctatus
(Bloch). International journal of environmental research and public health $7(8)$ : 3298-3312.

35. Hussein SY, El Nasser MA, Ahmed SM (1996) Comparative studies on the effects of herbicide Atrazine on freshwater fish Oreochromis niloticus and Chrysichthys auratus at Assiut Egypt. Bull Environ Contam Toxicol 57(3): 503-510.

36. Neškovic NK, Elezonic I, Karan V, Poleksic V, Budimir M (1993) Acute and subacute toxicity of atrazine to Carp (Cyprinus carpio). Ecotoxicol Environ Saf 25(2): 173-182.

37. Bathe R, Ullmann L, Sachsse K (1973) Determination of pesticide toxicity to fish. Berlin-Dahlem 37: 241-246.

38. Abarikwu SO, Farombi EO (2015) Atrazine induces apoptosis of SHSY5Y human neuroblastoma cells via the regulation of Bax/Bcl-2 ratio and caspase-3-dependent pathway. Pestic Biochem Physiol 118: 90-98.

39. Chen D, Zhang Z, Yao H, Liang Y, Xing H, Xu S (2015) Effects of atrazine and chlorpyrifos on oxidative stress-induced autophagy in the immune organs of common carp (Cyprinus carpio L.). Fish Shellfish Immunol $44(1): 12-20$

40. Thomas P, Dong J (2006) Binding and activation of the seven trans-membrane estrogen receptor GPR30 by environmental estrogens: a potential novel mechanism of endocrine disruption. J Steroid Biochem Mol Biol 102(1-5): 175-179.

41. Heneweer M, Van den Berg M, Sanderson J (2004) A comparison of human H295R and rat R2C cell lines as in vitro screening tools for effects on aromatase. Toxicol Lett 146(2): 183-194.

42. Rich JD, Gabriel SM, Schultz Norton JR (2012) In vitro effects of herbicides and insecticides on human breast cells. ISRN toxicology p.9.

43. Rudolph A, Chang-Claude J, Schmidt MK (2016) Gene-environment interaction and risk of breast cancer. Br J Cancer 114(2): 125-133. 